\title{
KAJIAN PEMANFAATAN ARANG SEKAM PADI AKTIF SEBAGAI PENGOLAH AIR LIMBAH GASIFIKASI
}

\author{
Frita Yuliati dan Herri Susanto* \\ Program Studi Teknik Kimia, Fakultas Teknologi Industri \\ Institut Teknologi Bandung \\ Jl. Ganesha 10 Bandung 40132 \\ Email : herri@che.itb.ac.id
}

\begin{abstract}
Abstrak
Adsorpsi dengan arang aktif merupakan salah satu cara pengolahan air limbah yang mengandung senyawa-senyawa turunan fenol. Pemanfaatan sekam padi diharapkan dapat menghasilkan arang aktif yang murah, sehingga penggunaannya dapat mengurangi biaya operasi di dalam pengolahan air limbah industri. Prosedur pembuatan arang aktif sederhana telah dikembangkan di laboratorium, yaitu aktivasi arang sekam padi dengan larutan $\mathrm{NaOH}$ $0,5 \mathrm{M}$, pada titik didih atmosferik dan selama $3 \mathrm{jam}$. Arang aktif yang diperoleh memiliki luas permukaan spesifik $145 \mathrm{~m}^{2} / \mathrm{g}$ dan kapasitas adsorpsi fenol sekitar 1,35 mg/g dari air limbah gasifikasi yang mengandung fenol antara $39-44 \mathrm{mg} / \mathrm{L}$. Laju adsorpsi fenol sesuai dengan persamaan pseudo-orde 1 Lagergren, sehingga diduga proses adsorpsi yang dominan dalam percobaan ini adalah adsorpsi fisik. Atas dasar hasil percobaan ini, sebuah unit usaha kecil/menengah diusulkan untuk dikembangkan bersamaan dengan unit penggilingan gabah yang banyak terdapat di pantai utara Jawa Barat. Unit produksi ini dirancang untuk menghasilkan arang aktif dengan kapasitas $480 \mathrm{~kg} / \mathrm{hari}$ atas dasar kapasitas penggilingan gabah 30 ton/hari. Dengan asumsi umur pabrik 8 tahun, harga arang sekam aktif sebesar Rp $5.000 / \mathrm{kg}$, investasi sebesar Rp 545 juta menghasilkan NPV sebesar Rp 1,22 miliar dan ROI sebesar $27 \%$.
\end{abstract}

Kata Kunci: Sekam Padi, Arang Aktif, Air Limbah, Adsorpsi Fenol, Kelayakan Ekonomi

\begin{abstract}
Our laboratory works showed that activated char with a spesific surface area of $145 \mathrm{~m}^{2} / \mathrm{g}$ and adsorption capacity of $1.35 \mathrm{mg} / \mathrm{g}$ could be prepared by activating rice husk char using $0.5 \mathrm{M}$ of $\mathrm{NaOH}$ solution, at $92{ }^{\circ} \mathrm{C}$ (boiling point at atmospheric pressure) for 3 hours. Using this simple process, a cheap activated char could be produced, so that the cost of wastewater treatment might be reduced. Base on common rice mill capacity of 6 tonnes/day in north part of West Java, a production of activated char with a daily capacity of $480 \mathrm{~kg}$ might be expected. With assumptions of a plant life time of 8 years, an activated char price is Rp $5,000 / \mathrm{kg}$, and an investment of Rp 545 millions, a production unit of activated char based on rice husk was found to be economically atractive with estimated Net Present Value of Rp 1.22 billions and Return on Investment of $27 \%$.
\end{abstract}

Keywords: Rice Husk, Activated Char, Wastewater, Phenol Adsorption, Economic Feasibility

*korespondensi 


\section{Pendahuluan}

Fenol dan senyawa-senyawa turunannya merupakan zat bersifat racun yang terdapat dalam air limbah yang dihasilkan oleh berbagai industri, di antaranya industri tekstil, cat, farmasi, dan kayu lapis. Salah satu cara pengolahan limbah mengandung senyawa-senyawa fenol adalah adsorpsi menggunakan arang aktif.

Arang aktif dapat diproduksi dari berbagai bahan seperti batubara, kayu, tempurung kelapa, dan sekam padi. Sekam padi merupakan limbah pertanian padi yang tersedia dalam jumlah besar di berbagai tempat Indonesia. Berat sekam yang dihasilkan adalah $22 \%$ dari berat gabah kering giling (Pakpahan, 2006). Sedangkan produksi gabah kering giling Indonesia pada tahun 2008 mencapai 60,25 juta ton (data BPS). Saat ini, umumnya sekam padi digunakan sebagai alas kandang pada peternakan ayam, arang untuk media tanam, atau dibuang begitu saja.

Sekam padi dapat dimanfaatkan sebagai bahan bakar pembangkit listrik melalui proses gasifikasi. Sekam padi digasifikasi untuk menghasilkan gas produser, yang kemudian digunakan sebagai bahan bakar pengganti sebagian bahan bakar solar pada Pembangkit Listrik Tenaga Diesel (PLTD). Untuk itu, gas produser perlu dibersihkan dari pengotor seperti tar dan partikel padatan. Proses pembersihan ini umumnya dilakukan dengan menggunakan water scrubber, yang menghasilkan air limbah mengandung fenol dalam konsentrasi tinggi, yaitu antara 300-3500 ppm. Terutama karena fenol merupakan senyawa yang bersifat racun, air limbah pembersihan gas produser ini perlu diolah sebelum dibuang ke lingkungan.

Penelitian di Program Studi Teknik Kimia ITB telah membuktikan bahwa arang sekam padi aktif dapat digunakan untuk mengadsorpsi fenol (Samudera, 2008; Yuliati, 2009; Yuliati dkk, 2009). Di dalam makalah ini, disampaikan secara ringkas hasil penelitian laboratorium tentang pembuatan arang aktif dari sekam padi dalam rangka mencari solusi penanganan air limbah pada unit gasifikasi sekam. Bahan baku pembuatan arang aktif adalah arang sekam padi sisa proses gasifikasi di PLTD-Sekam. PLTDSekam ini merupakan unit demonstrasi untuk memproduksi listrik dari sekam padi melalui proses gasifikasi yang terdapat di desa Haurgeulis, Indramayu (Susanto, 2005). Hasil yang disampaikan dalam makalah ini merupakan pengembangan dari penelitian sebelumnya yang menggunakan arang sekam padi hasil gasifikasi skala laboratorium (Samudera, 2009). Pengembangan ini dimaksudkan untuk memperoleh gambaran yang lebih jelas mengenai potensi arang sekam padi sisa gasifikasi sebagai bahan pembuatan arang aktif pada skala industri kecil/menengah.

Pembuatan arang aktif yang disampaikan dalam makalah ini sangat sederhana, sehingga sesuai untuk diterapkan di wilayah pertanian padi. Berdasarkan prosedur tersebut, diusulkan pendirian suatu unit usaha kecil/menengah yang dapat meningkatkan kegiatan ekonomi daerah, khususnya di sekitar unit penggilingan gabah. Untuk itu perlu dilakukan kajian kelayakan ekonomi, seperti yang disajikan dalam makalah ini. Adapun kapasitas produksi arang aktif disesuaikan dengan kapasitas produksi penggilingan gabah yang umum terdapat sentra-sentra produksi beras di Jawa Barat.

\section{Fundamental}

Model sederhana yang sering digunakan untuk menyatakan laju adsorpsi adalah persamaan pseudo orde pertama Lagergren (persamaan 1, di bawah ini). Persamaan ini menggunakan asumsi bahwa perpindahan massa merupakan tahap penentu laju adsorpsi, dan adsorpsi yang terjadi didominasi oleh adsorpsi fisik.

$$
\frac{d q_{t}}{d t}=k_{1}\left(q_{e}-q_{t}\right)
$$

Persamaan laju adsorpsi lain yang sering digunakan adalah persamaan pseudo-orde kedua (persamaan 2, Ho dan McKay, 1999).

$\frac{d q_{t}}{d t}=k_{2}\left(q_{e}-q_{t}\right)^{2}$

Dengan $\mathrm{q}_{\mathrm{t}}$ adalah jumlah adsorbat yang teradsorpsi pada waktu tertentu, qe adalah jumlah adsorbat yang teradsorpsi setelah kesetimbangan tercapai, $\mathrm{k}_{1}$ adalah konstanta laju adsorpsi orde 1, dan $\mathrm{k}_{2}$ adalah konstanta laju adsorpsi orde 2 .

Produksi karbon aktif dari sekam padi dilakukan dalam dua tahap utama, yaitu karbonisasi dan aktivasi dengan senyawa basa (Hassler, 1951; Benke dkk., 2006). Pada aktivasi menggunakan larutan $\mathrm{NaOH} \mathrm{0,5} \mathrm{M,}$ luas permukaan spesifik berbanding lurus 
dengan jumlah silika tersisihkan dari arang sekam padi. Kenaikan temperatur aktivasi dapat meningkatkan jumlah silika yang tersisihkan. Penyisihan $75 \%$ silika pada aktivasi dengan larutan $\mathrm{NaOH} 0,5 \mathrm{M}$ pada temperatur $80^{\circ} \mathrm{C}$ selama 2 jam menghasilkan arang sekam aktif dengan luas permukaan spesifik sebesar $285 \mathrm{~m}^{2} / \mathrm{g}$ (Benke, 2006). Arang sekam padi yang diaktivasi menggunakan larutan $\mathrm{H}_{2} \mathrm{SO}_{4} 49 \%(6,98 \mathrm{M})$ dapat mengadsorpsi $17,63 \mathrm{mg}$ fenol/g adsorben dari larutan fenol $250 \mathrm{mg} / \mathrm{L}$ (Samudera, 2008). Aktivasi arang sekam padi dengan larutan $\mathrm{NaOH}$ 0,5 M menghasilkan adsorben yang dapat mengadsorpsi 7,7 mg fenol/g adsorben dari larutan fenol $250 \mathrm{mg} / \mathrm{L}$ (Yuliati dkk., 2009). Sebagai pembanding, arang aktif komersial berbahan tempurung kelapa dapat menyerap 13,35 mg fenol/g adsorben dari larutan yang sama. Arang sekam padi yang digunakan dalam penelitian tersebut merupakan limbah dari gasifikasi sekam padi. Namun proses aktivasi dalam penelitian tersebut dapat pula digunakan untuk arang sekam padi yang diproduksi secara khusus dan bukan merupakan limbah proses lain.

\section{Metodologi}

Arang aktif sekam padi diaktivasi secara kimia menggunakan larutan $\mathrm{NaOH} \mathrm{0,5}$ $\mathrm{M}$ pada temperatur ruang (kode adsorben AN1, lihat Tabel 1), larutan $\mathrm{NaOH} 0,5 \mathrm{M}$ mendidih (kode adsorben AN2), dan larutan $\mathrm{NaOH} 1 \mathrm{M}$ pada temperatur ruang (kode adsorben AN3). Peralatan yang digunakan adalah gelas kimia dan magnetic stirrer untuk aktivasi pada temperatur ruang, dan menggunakan labu erlenmeyer, kondensor gelas untuk refluks, dan magnetic stirrer untuk aktivasi dengan larutan mendidih. Volume larutan yang digunakan adalah $5 \mathrm{~mL}$ untuk setiap gram arang sekam padi. Karakteristik arang aktif dibandingkan dengan arang sekam yang tidak diaktivasi (kode ASP) dan produk karbon aktif komersial (dinamai "KBW" produksi suatu pabrik di Bandung).

Sifat adsorben yang diuji dalam penelitian ini adalah karakteristik permukaan dan diameter pori, kadar abu adsorben, serta kapasitas adsorpsi fenol. Karakteristik permukaan dan diameter pori adsorben dianalisis dengan Quantachrome Nova 1000 Surface Area and Pore Size Analyzer. Kadar abu diukur dari perbandingan massa sisa pembakaran adsorben pada $750{ }^{\circ} \mathrm{C}$ selama satu jam dengan massa adsorben sebelum pembakaran. Kapasitas adsorpsi fenol seluruh adsorben tersebut diuji menggunakan air limbah dari PLTD-G Sekam Haurgeulis yang mengandung 39-44 mg/L fenol. Uji kapasitas adsorpsi dilakukan dengan cara mengontakkan $1 \mathrm{~g}$ adsorben dengan $100 \mathrm{~mL}$ larutan, pada $\mathrm{pH}$ yang tidak diatur, pada temperatur ruangan. Jumlah fenol yang teradsorpsi dihitung dari perbedaan konsentrasi larutan sebelum dan sesudah diadsorpsi selama 30,60, 90, dan 120 menit. Analisis konsentrasi fenol dilakukan dengan metode 4-aminoantipirin. Hasil percobaan kinetika adsorpsi dibandingkan dengan model yang dibuat menggunakan persamaan laju adsorpsi orde 1 dan 2. Kondisi penyiapan absorben ditampilkan pada Tabel 1.

Pada rencana pabrik arang sekam aktif, produksi dilakukan secara batch, dengan tahap-tahap produksi berdasarkan percobaan laboratorium yang menghasilkan adsorben dengan kapasitas adosrpsi fenol terbaik. Perolehan pada tiap tahap dihitung berdasarkan percobaan yang telah dilakukan di Teknik Kimia ITB (Yuliati, 2009).

Kajian kelayakan ekonomi dilakukan dengan menghitung variabel-variabel seperti investasi, pendapatan, biaya produksi, serta pajak dan suku bunga. Investasi dihitung berdasarkan kapasitas peralatan yang

Tabel 1. Kode adsorben yang digunakan dalam penelitian ini

\begin{tabular}{cccr}
\hline \multirow{2}{*}{ Kode Adsorben } & Bahan Absorben & \multicolumn{2}{c}{ Aktivasi } \\
\cline { 3 - 4 } & & Larutan Aktifasi & Temperatur (oC) \\
\hline ASP & arang sekam padi & NaOH 0,5 M & - \\
AN2 & arang sekam padi & NaOH 0,5 M & $27-29$ \\
AN2 & arang sekam padi & NaOH 1 M & $27-29$ \\
AN3 & arang sekam padi & - & - \\
KBW & karbon aktif komersial & & \\
\hline
\end{tabular}


dihitung berdasarkan hasil percobaan dan jumlah sekam padi yang tersedia. Biaya produksi meliputi pengadaan bahan baku, biaya listrik, gaji pegawai, pemeliharaan alat, pengolahan limbah, dan depresiasi peralatan. Kelayakan ekonomi ditunjukkan dengan hasil perhitungan NPV (Net Present Value) dan ROI (Return on Investment).

\section{Hasil dan Pembahasan}

\section{Hasil Percobaan Laboratorium}

Aktivasi arang sekam padi dengan larutan $\mathrm{NaOH}$ menghasilkan arang sekam padi aktif (adsorben AN1, AN2, dan AN3) dengan luas permukaan spesifik yang lebih besar daripada ASP. Hasil percobaan tersebut sesuai dengan teori yang menyatakan bahwa senyawa basa sesuai untuk digunakan dalam aktivasi arang sekam padi, karena senyawa basa dapat menyisihkan abu dari arang sekam padi (Hassler, 1951). Hubungan antara kadar abu dengan luas permukaan spesifik

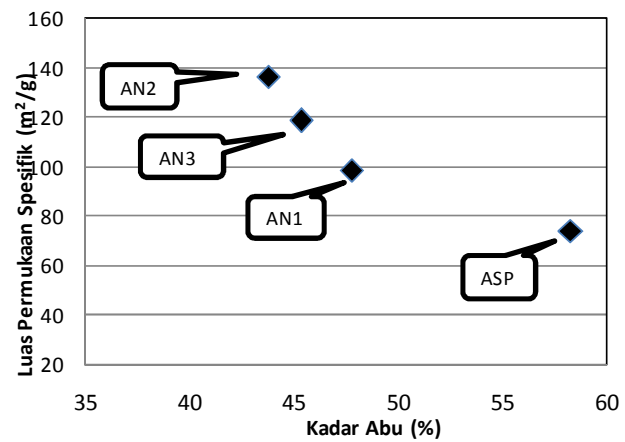

Gambar 1. Hubungan antara kadar abu dan luas permukaan spesifik adsorben ditampilkan pada Gambar 1. Dalam penelitian ini diasumsikan bahwa seluruh abu dalam arang sekam terdiri dari silika, sehingga silika yang tersisihkan dalam proses aktivasi dianggap sebagai kadar abu yang tersisihkan.

Adsorben yang dihasilkan dalam percobaan diuji kapasitasnya untuk adsorpsi fenol dari air limbah gasifikasi. Kapasitas adsorpsi arang-arang aktif tersebut dibandingkan satu sama lain untuk memperoleh adsorben yang terbaik untuk menyisihkan fenol. Hasil uji kinetika adsorpsi berbagai adsorben yang digunakan dalam penelitian ini ditampilkan pada Gambar 2.

Aktivasi menggunakan larutan $\mathrm{NaOH}$ 0,5 M meningkatkan kapasitas adsorpsi fenol arang sekam padi. Hal ini berkaitan dengan peningkatan luas permukaan spesifik arang sekam setelah aktivasi, yang disebabkan oleh terlarutnya sebagian abu dari arang (Hassler, 1951).

Luas permukaan spesifik suatu adsorben merupakan parameter yang umum digunakan dalam identifikasi suatu adsorben. Pada Gambar 3 tampak bahwa luas permukaan spesifik adsorben merupakan faktor penting yang mempengaruhi kapasitas adsorpsi fenol adsorben. Kecenderungan ini sesuai dengan hasil penelitian lain yang menyebutkan bahwa adsorpsi fenol terbatas pada pembentukan lapisan tunggal pada permukaan terbuka dan dinding mikropori, sehingga luas permukaan spesifik merupakan faktor yang menentukan

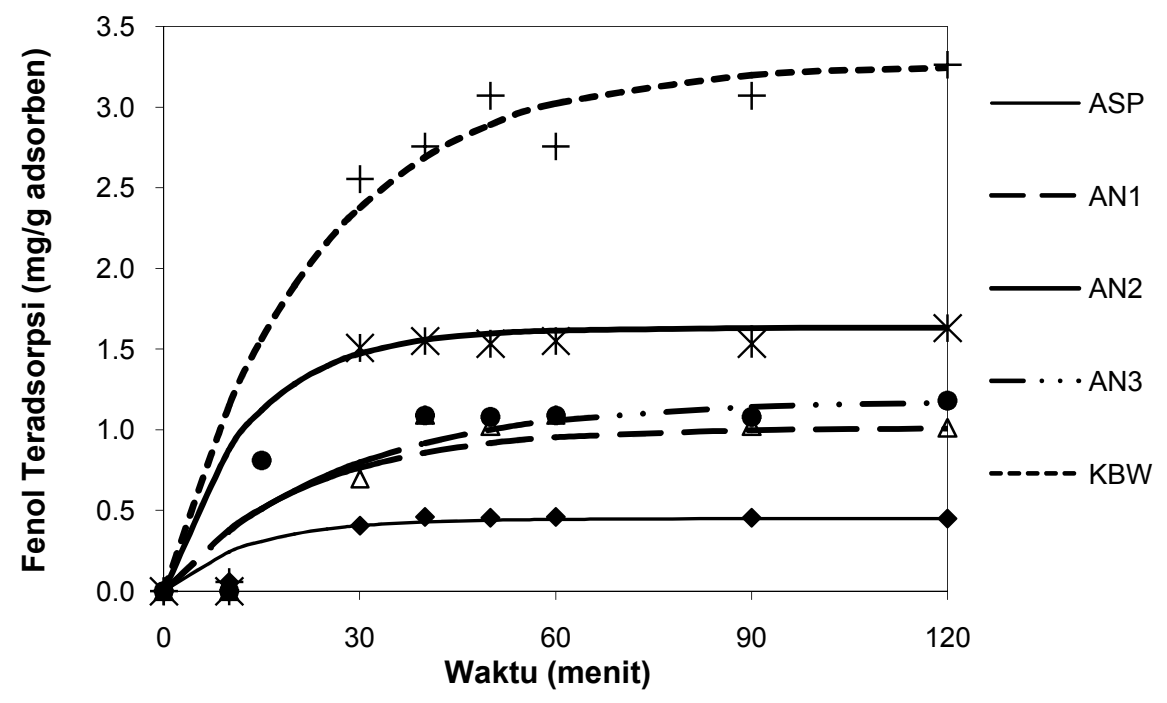

Gambar 2. Hasil uji laju adsorpsi fenol dari air limbah gasifikasi 


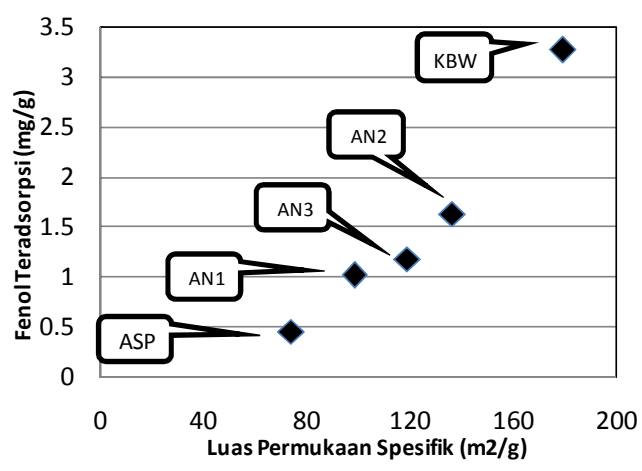

Gambar 3. Hubungan antara jumlah fenol teradsorpsi dari air limbah gasifikasi dengan luas permukaan spesifik adsorben

kapasitas adsorpsi fenol (Stoeckli dan HugiCleary, 2001). Luas permukaan adsorben yang dihasilkan dalam penelitian ini lebih rendah daripada luas permukaan karbon aktif komersial yang digunakan sebagai pembanding (KBW). Hal ini menjelaskan lebih tingginya kapasitas adsorpsi fenol oleh karbon aktif komersial dibandingkan arang sekam aktif yang dihasilkan dalam penelitian ini.

Laju adsorpsi tiap adsorben dimodelkan dengan persamaan pseudo orde pertama Lagergren, menghasilkan nilai konstanta laju adsorpsi (k, persamaan 1; lihat Tabel 2; $\mathrm{R}^{2}$ adalah koefisien regresi). Model ini cukup sesuai untuk peristiwa adsorpsi yang terjadi dalam percobaan, ditunjukkan dengan besarnya nilai $\mathrm{R}^{2}$ yang diperoleh. Hal ini menunjukkan bahwa laju adsorpsi dikendalikan oleh perpindahan massa dari larutan ke permukaan adsorben. Dengan demikian dapat diduga bahwa adsorpsi fisik merupakan peristiwa yang dominan pada proses adsorpsi yang dilakukan dalam percobaan (Ho dan McKay, 1999).

Tabel 2. Konstanta laju adsorpsi fenol dari air limbah gasifikasi

\begin{tabular}{ccc}
\hline Adsorben & $\mathbf{k}$ & $\mathbf{R}^{\mathbf{2}}$ \\
\hline ASP & 0,077 & 0,996 \\
AN1 & 0,047 & 0,980 \\
AN2 & 0,091 & 0,991 \\
AN3 & 0,038 & 0,995 \\
KBW & 0,043 & 0,989 \\
\hline
\end{tabular}

\section{Rencana pabrik arang sekam aktif skala} kecil

Pabrik arang sekam aktif skala kecil ini direncanakan untuk memanfaatkan limbah sekam padi dari penggilingan gabah di daerah Indramayu, Jawa Barat. Kapasitas penggilingan gabah milik perorangan yang umum adalah 30 ton gabah kering giling per hari, sehingga sekam padi yang dihasilkan adalah sekitar 6 ton per hari. Kondisi pembuatan arang aktif AN2 diambil sebagai referensi dalam pra-rancangan pabrik arang aktif. Diagram alir proses ditampilkan pada Gambar 4, dijelaskan dengan neraca massa pada Tabel 3. Pada gambar tersebut, sekam padi masuk sebagai bahan baku proses pembakaran pada Aliran 1, Larutan $\mathrm{NaOH}$ sebagai aktivator masuk pada Aliran 6, abu sekam padi sebagai sisa pembakaran keluar pada Aliran 16, dan air untuk keperluan pencucian masuk pada Aliran 3 dan 9.

Produksi arang sekam padi aktif dimulai dengan produksi arang sekam padi. Produksi arang dilakukan dalam sebuah tungku yang memiliki pengatur aliran udara. Pembakaran sekam padi dalam tungku ini menghasilkan panas yang digunakan dalam aktivasi arang sekam padi. Aliran udara diatur sedemikian rupa, sehingga dapat dihasilkan arang dengan kadar karbon yang diinginkan. Arang yang diperoleh dalam proses tersebut diaktivasi untuk meningkatkan kapasitasnya dalam mengadsorpsi fenol. Aktivasi dilakukan dengan mengontakkan arang sekam padi dengan larutan $\mathrm{NaOH} \mathrm{0,5} \mathrm{M} \mathrm{mendidih} \mathrm{selama}$ 3 jam. Kemudian arang sekam aktif dicuci untuk menyisihkan $\mathrm{NaOH}$ dari arang dan dikeringkan. Dengan asumsi pabrik arang sekam padi aktif menggunakan seluruh sekam yang dihasilkan satu unit penggilingan gabah, arang aktif yang diperoleh adalah 480 $\mathrm{kg} /$ hari.

Unit produksi arang sekam padi aktif ini terdiri dari alat-alat berikut.

a. Satu unit tungku berbahan bakar sekam padi sebagai sumber panas pada proses pencucian dan aktivasi arang sekam padi, dan sekaligus untuk memproduksi arang sekam padi dengan rancangan tube-inbasket burner, (Kapur, 1984). Tungku ini memiliki diameter luar 3,0 m, tinggi 3,0 $\mathrm{m}$, dan diameter tube $1,13 \mathrm{~m}$, dibuat dengan material stainless steel.

b. Satu unit tangki berpengaduk untuk pencucian dan aktivasi arang sekam padi. Diameter tangki adalah 3,75 m, dengan tinggi $0,95 \mathrm{~m}$. Tangki dan pengaduk dibuat dari stainless steel. 


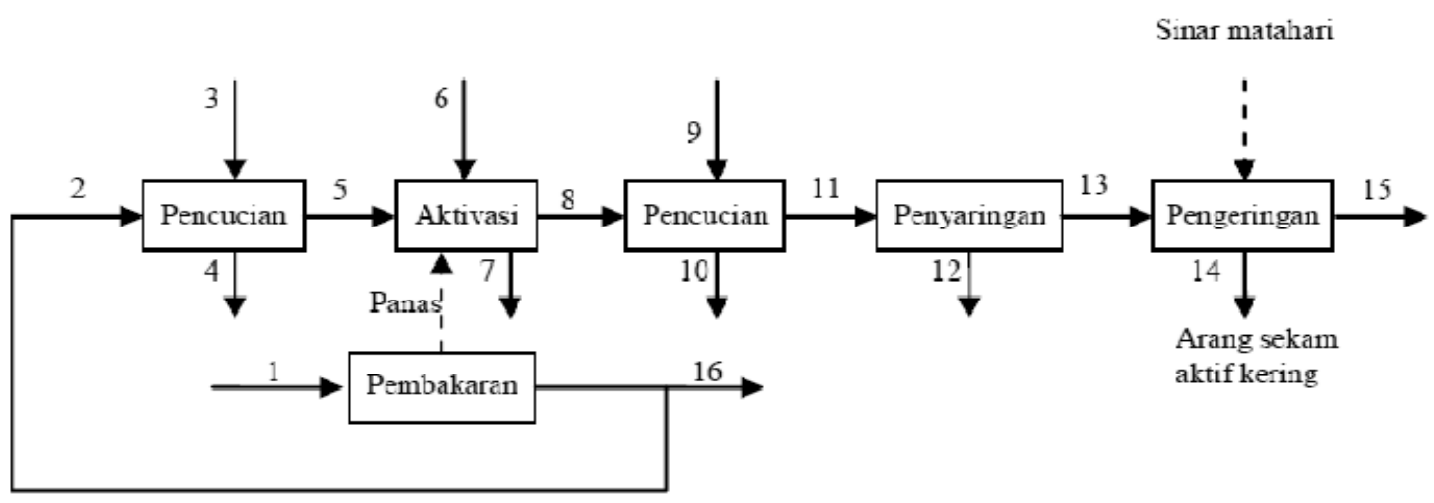

Gambar 4. Diagram alir produksi arang sekam padi aktif

Tabel 3. Neraca massa produksi arang sekam aktif skala kecil

\begin{tabular}{lrrrrrrrr}
\hline & \multicolumn{7}{c}{ Laju Alir (kg/hari) } \\
\hline Aliran & 1 & 2 & 3 & 4 & 5 & 6 & 7 & \multicolumn{1}{c}{8} \\
\hline Sekam padi & 6.000 & & & & & & & 658 \\
Arang sekam padi & & 1.077 & & 60 & 1.017 & & & 6.847 \\
Air & & 120 & 5.985 & 3.618 & 2.367 & 3.019 & 3.840 \\
NaOH & & & & & & 120 & 118 & \\
Silika dan karbon & & & & & & 359 & \\
Abu sekam padi & & & & & & & & \\
\hline
\end{tabular}

Tabel 3 (lanjutan)

\begin{tabular}{|c|c|c|c|c|c|c|c|c|}
\hline \multirow[b]{2}{*}{ Aliran } & \multicolumn{8}{|c|}{ Laju Alir (kg/hari) } \\
\hline & 9 & 10 & 11 & 12 & 13 & 14 & 15 & 16 \\
\hline \multicolumn{9}{|l|}{ Sekam padi } \\
\hline Arang sekam padi & & & 426 & & 426 & 426 & & \\
\hline Air & 76.991 & 74.269 & 4.261 & 3.267 & 994 & 53 & 942 & \\
\hline $\mathrm{NaOH}$ & & 2 & & & & & & \\
\hline Silika dan karbon & & 232 & & & & & & \\
\hline Abu sekam padi & & & & & & & & 199 \\
\hline
\end{tabular}

c. Satu unit penyaring untuk memisahkan arang sekam dari air setelah pencucian, dengan diameter $2 \mathrm{~m}$, dengan material stainless steel.

d. Satu unit pengering arang sekam aktif bertenaga matahari yang terdiri dari satu ruang pengeringan berukuran 2,4 x 1,3 x 0,5 m yang berisi rak 6 susun untuk meletakkan arang sekam aktif yang akan dikeringkan. Sirkulasi udara diatur menggunakan satu unit blower. Rancangan pengering ini diadaptasi dari rancangan pengering oleh Chandak dkk., 2009.

Asumsi-asumsi yang digunakan dalam perhitungan kelayakan ekonomi adalah sebagai berikut.

a. Umur pabrik adalah 8 tahun. b. Seluruh biaya investasi diperoleh dari modal sendiri sebesar $50 \%$ dan sisanya dari hutang.

c. Penggilingan gabah menghasilkan limbah sekam padi sebesar 6 ton/hari. Seluruh sekam padi digunakan sebagai bahan bakar, dan arang sekam padi yang digunakan sebagai bahan pembuatan arang aktif adalah sisa pembakaran.

d. Harga pengadaan lahan adalah nol.

e. Pembangunan fasilitas ini berlangsung selama 6 bulan, sehingga produksi dapat dimulai pada semester ke- 2 tahun ke- 0 .

f. Depresiasi dihitung dengan metode straight line.

g. Harga perolehan arang sekam padi adalah nol.

h. Harga bahan bakar sekam padi adalah nol.

i. Harga jual arang sekam padi aktif adalah Rp 5.000,00 / kg. 
Tabel 4. Evaluasi kelayakan ekonomi pabrik arang sekam padi aktif untuk umur pabrik 8 tahun

\begin{tabular}{lr}
\hline Pendapatan & \multicolumn{1}{c}{ Nilai (Rp) } \\
\hline Penjualan arang sekam aktif & 717.883 .844 \\
Penjualan abu sekam & 29.800 .514 \\
\hline Pengeluaran & \\
\hline Investasi & 545.199 .651 \\
NaOH & 190.239 .219 \\
Listrik & 35.027 .201 \\
Gaji (4 orang pegawai) & 38.400 .000 \\
Perawatan alat & 10.903 .993 \\
Pengolahan limbah & 13.629 .991 \\
Penyimpanan produk & 35.894 .192 \\
Depresiasi & 43.685 .869 \\
Laba Kotor & 379.903 .893 \\
\hline Kewajiban Hutang & \\
\hline Pokok hutang & 34.074 .978 \\
Bunga & 4.429 .747 \\
\hline Laba kotor - kewajiban & 341.399 .167 \\
hutang & \\
Pajak & 51.209 .875 \\
Laba bersih & 290.189 .292 \\
\hline NPV & 1.507 .294 .608 \\
ROI (\%) & 27.02 \\
\hline
\end{tabular}

Hasil perhitungan kelayakan ekonomi berdasarkan metode perhitungan pada buku Chemical Engineering Economics (Garret, 1989) ditampilkan pada Tabel 4. Investasi yang diperlukan untuk membangun pabrik arang sekam aktif ini adalah Rp 545.199.501. Produksi arang sekam padi aktif dengan asumsi tersebut menghasilkan keekonomian yang cukup menarik, yaitu dengan NPV sebesar Rp 1.220.686.298, serta ROI sebesar $27,02 \%$. Pendapatan yang dihasilkan tiap tahun lebih besar daripada investasi. Akan tetapi, besarnya biaya operasi menyebabkan laba bersih bernilai rendah. Hal ini juga menyebabkan panjangnya waktu untuk mencapai break even, yaitu lebih dari 2 tahun (Gambar 5).

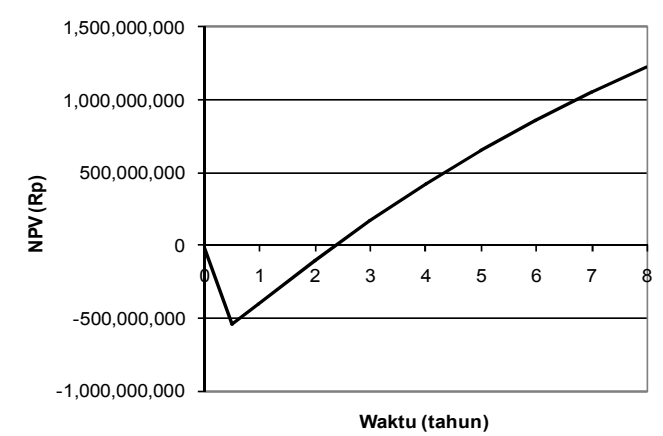

Gambar 5. NPV pabrik arang sekam padi aktif

Analisis sensitivitas pabrik arang sekam padi aktif menunjukkan bahwa keekonomian pabrik ini cukup sensitif terhadap kapasitas pabrik, penjualan, dan harga material $(\mathrm{NaOH})$. Keekonomian pabrik ini akan semakin baik apabila dibangun dalam kapasitas yang lebih besar dan ketika harga karbon aktif komersial semakin mahal. Analisis sensitivitas pabrik arang sekam padi aktif ditampilkan dalam Gambar 6.

Produksi arang aktif dari sekam padi oleh industri kecil dengan teknologi sederhana berpeluang untuk menyerap tenaga kerja di daerah penghasil beras. Pengoperasian pabrik tidaklah rumit,

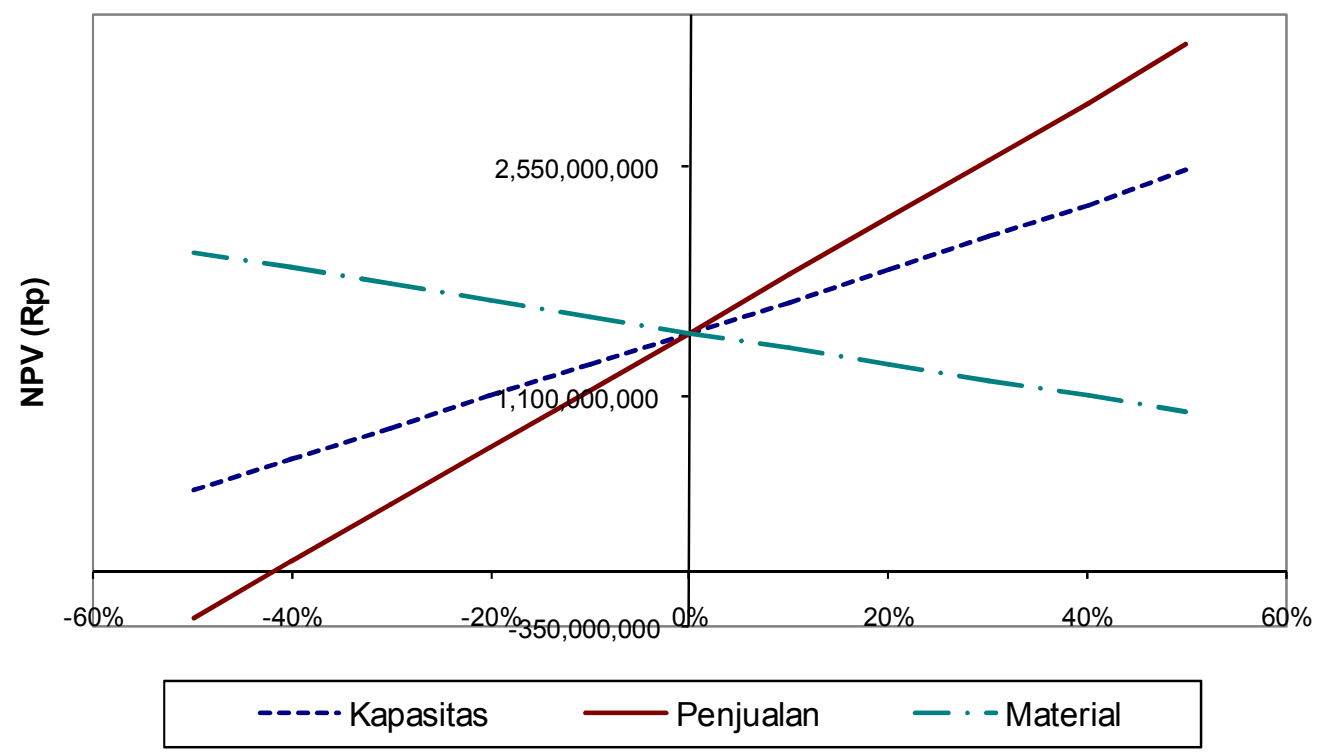

Gambar 6. Analisis sensitivitas pabrik arang sekam padi aktif 
sehingga tenaga kerja yang diperlukan tidak harus memiliki tingkat pendidikan yang tinggi. Dengan demikian, keberadaan pabrik ini diharapkan dapat meningkatkan kesejahteraan masyarakat pedesaan dan mengurangi laju urbanisasi.

Pemanfaatan sekam padi berarti memanfaatkan limbah yang sebelumnya tidak termanfaatkan. Pembuangan sekam padi dapat dihindari, sehingga produksi metana akibat pembusukan sekam dapat dikurangi. Metana merupakan gas rumah kaca dengan efek rumah kaca 28 kali lebih kuat dari $\mathrm{CO}_{2}$, sehingga penurunan produksinya memiliki peran dalam penyelamatan lingkungan. Di samping itu, penggunaan limbah yang memiliki harga rendah dapat menghasilkan arang aktif yang murah, sehingga penggunaannya dalam pengolahan limbah cukup menarik bagi kalangan pelaku industri.

\section{Kesimpulan}

Arang sekam padi aktif merupakan adsorben yang dapat digunakan dalam pengolahan limbah industri yang mengandung fenol dan senyawa turunannya. Aktivasi arang sekam menggunakan larutan $\mathrm{NaOH} 0,5 \mathrm{M}$ pada $92{ }^{\circ} \mathrm{C}$ meningkatkan luas permukaan dan kapasitas adsorpsi fenol lebih besar, jika dibandingkan terhadap aktifasi dengan larutan $\mathrm{NaOH} \mathrm{0,5} \mathrm{M} \mathrm{dan} 1 \mathrm{M}$ pada temperatur ruang. Proses adsorpsi yang terjadi adalah adsorpsi fisik.

Pra-rancangan pabrik arang aktif dari sekam padi telah disusun atas dasar skala penggilingan gabah di daerah Indramayu. Produksi arang aktif dari sekam padi dengan kapasitas 478,6 kg arang sekam aktif/hari cukup ternyata menarik secara ekonomis.

Pendirian pabrik arang sekam aktif di sentra-sentra padi diharapkan dapat meningkatkan kegiatan ekonomi setempat, penyerapan tenaga kerja, serta pengurangan permasalahan sekam padi yang belum termanfaatkan. Diharapkan pula unit produksi arang aktif dari sekam padi ini dikembangkan menjadi salah satu bagian dalam Badan Usaha Milik Petani (BUMP) yang akhir-akhir ini dicanangkan oleh pemerintah.

Untuk merealisasikan terwujudnya pabrik arang sekam aktif tersebut, dapat dilakukan penelitian lebih lanjut, yaitu tentang produksi arang sekam aktif skala pilot. Penelitian ini diharapkan dapat menjembatani proses skala laboratorium dengan skala komersial.

\section{Ucapan Terima Kasih}

Penulis menyampaikan terima kasih kepada Tanoto Foundation, Jakarta yang telah membiayai penelitian ini. Makalah ini terkait dengan pengembangan teknologi gasifikasi yang ramah lingkungan untuk memanfaatkan biomassa sebagai sumber energi terbarukan.

\section{Daftar Pustaka}

Badan Pusat Statistik, Harvested Area, Yield Rate and Production of Paddy by Province 2000-2008, www.bps.go.id/sector/agri/ pangan/tables.shtml, diakses tanggal 18 Juni 2009.

Benke, D.J.; Wainwright, M.S.; Nigam, K.D.P.; Rao, T.R., Kinetics of silica dissolution from rice husk char, The Canadian Journal of Chemical Engineering, 2006, Vol. 84(6), 689-692.

Chandak, A.; Somani, S.K.; Dubey, D., Design of solar dryer with turboventilator and fireplace, Proceedings of International Solar Food Processing Conference, Indore, India, January 2009.

Garrett, D.E., Chemical Engineering Economics, Van Nostrand Reinhold, New York, 1989, 8-97.

Hassler, J.W., Active Carbon, Chemical Publishing Co. Inc., New York, 1951.

Ho, Y.S.; McKay, G.; Pseudo-second order model for sorption processes, Process Biochemistry, 1999, Vol. 34(5), 451-465.

Kapur, P.C.; Singh, R.; Srinivasan, J., Tube-inbasket burner for rice husk I: Properties of husk as a fuel and basic design considerations, Sadhana, 1984, Vol. 7(4), 291-300.

Pakpahan, A., Sekam Padi, Sebuah Alternatif Sumber Energi, www.batan.go.id /bkhh/ BagianHumas/KlippingBerita/Klipping2006/ SekamPadi,SebuahAlternatifSumberEnergi_S P_28Sept06.htm. Diakses pada 12 Juni 2007.

Samudera, T.F., Uji karakteristik fisik dan kapasitas adsorpsi arang sekam padi sebagai adsorben fenol dari air limbah gasifikasi 
biomassa, Tesis Magister, Program Studi Magister Teknik Kimia, Fakultas Teknologi Industri, Institut Teknologi Bandung, 2008.

Stoeckli, F.; Hugi-Cleary, D., On the mechanism of phenol adsorption by carbons, Russian Chemical Bulletin, 2001, Vol. 50(11), 20602063.

Susanto, H., Pengujian PLTD Gasifikasi Sekam $100 \mathrm{~kW}$ di Haur Geulis, Indramayu, Laporan Proyek Kerja Sama, DJLEB dengan Departemen Teknik Kimia ITB, 2005.
Yuliati, F., "Pemanfaatan Arang Sekam Padi Aktif sebagai Pengolah Air Limbah Gasifikasi", Tesis Magister, Program Studi Magister Teknik Kimia, Fakultas Teknologi Industri, Institut Teknologi Bandung, 2009.

Yuliati, F., Susanto, H., Sasongko, D., Utilization of activated char from rice husk for gasification wastewater treatment, Proceeding of ASEAN Regional Symposium on Chemical Engineering, Manila 1-2 December 2009. 